\title{
Pengaruh Internasionalisasi, Afiliasi Bisnis, dan Research \& Development terhadap Kinerja Perusahaan Manufaktur di Indonesia
}

\author{
Prastica Astrid Octaviandini Chadys ${ }^{1}$, Liyu Adhi Kasari Sulung ${ }^{2 *}$, Mutiara Baby Admeinasthi ${ }^{3}$ \\ Departemen Manajemen, Fakultas Ekonomi dan Bisnis, Universitas Indonesia, \\ Jl. Prof. Dr. Sumitro Djojohadikusumo, Depok, 16424, Indonesia \\ *Corresponding author's email: liyu.adhi@ui.ac.id
}

Received: 26-10-2017, Accepted: 16-03-2018, Published: 2-04-2018

\begin{abstract}
This study aims to identify the influence of internationalization, the number of business affiliation, the existence of business affiliation abroad, and the intensity of $R \& D$ on the performance of manufacturing companies listed at the Indonesia Stock Exchange during the period of 2011-2015. This study measures company's internationality using the ratio of company's foreign sales to its total sales. The number of business affiliation owned by the company is counted based on the data recorded in the company's financial report. The existence of company's business affiliation abroad is indicated by dummy variable. The intensity of company's $R \& D$ is measured using the ratio of $R \& D$ expenditure to company's total sales. Meanwhile, firm performance is measured by using two proxies, i.e. Return on Assets (ROA) and Tobin's Q. By means of panel data analysis, the result of this study shows that internationalization negatively affects firm performance, the number of business affiliation positively affects the ROA but negatively affects Tobin's $Q$, andthe existence of affiliation abroad and the $R \& D$ intensity positively affect firm performance.
\end{abstract}

Keywords: internationalization, business group affiliation, research \& development, company performance, manufacturing firm

\begin{abstract}
Abstrak
Penelitian ini bertujuan untuk mengidentifikasi pengaruh internasionalisasi, jumlah afiliasi bisnis, keberadaan afiliasi bisnis di luar negeri, dan intensitas riset dan pengembangan terhadap kinerja perusahaan-perusahaan manufaktur yang terdaftar di Bursa Efek Indonesia pada periode 2011-2015. Penelitian ini mengukur internasionalitas perusahaan dengan menggunakan rasio penjualan perusahaan di luar negeri terhadap total penjualan perusahaan. Jumlah afiliasi bisnis yang dimiliki perusahaan dihitung berdasarkan data yang terdapat pada laporan keuangan perusahaan. Keberadaan afiliasi bisnis perusahaan di luar negeri digambarkan dengan variabel dummy. Intensitas riset dan pengembangan perusahaan diukur menggunakan rasio biaya riset dan pengembangan terhadap total penjualan perusahaan. Sementara, kinerja perusahaan diukur dengan menggunakan dua proksi, yaitu Return on Assets (ROA) dan Tobin's $Q$. Dengan menggunakan analisis data panel, hasil dari penelitian ini menunjukkan bahwa internasionalisasi berpengaruh negatif terhadap kinerja perusahaan, jumlah afiliasi bisnis berpengaruh positif terhadap ROA namun berpengaruh negatif terhadap Tobin's $Q$, dan keberadaan afiliasi di luar negeri serta intensitas riset dan pengembangan berpengaruh positif terhadap kinerja perusahaan.
\end{abstract}

Kata kunci: Internasionalisasi, afiliasi bisnis, research \& development, kinerja perusahaan, manufaktur JEL: M16 DOI: 10.20885/jsb.vol22.iss1.art4

\section{Pendahuluan}

Ekspor dunia terus memperlihatkan pertumbuhannya dari tahun ke tahun dan hal ini memberikan pengaruh pada bisnis internasional dan ekonomi dunia secara umum (Yaprak, Yosun, \& Cetindamar, 2017). Hal ini pun memberikan dampak positif pada ekspor Indonesia yang juga mengalami peningkatan yang cukup signifikan pada beberapa tahun terakhir. Berdasarkan data dari 
trading economics (2017), tren ekspor Indonesia cenderung mengalami kenaikan dari tahun 2006 hingga tahun 2016, walaupun sempat mengalami penurunan nilai ekspor dari tahun 2009 sampai dengan tahun 2015 akibat krisis keuangan global.

Peningkatan perdagangan internasional secara global ini menjadi fokus terkini di beberapa studi literatur dikarenakan pertumbuhan internasionalisasi dapat memberikan dampak ekonomi jangka panjang pada suatu negara. Penelitian-penelitian sebelumnya telah meneliti dampak dari faktor internasionalisasi pada kinerja perusahaan (Boso, Adeola, Danso, \& Assadinia, 2017; Chen \& Hsu, 2010; Demirkesen \& Ozorhon, 2017; Miller, Lavie, \& Delios, 2016; Purnama \& Subroto, 2016; Upadhyayula, Dhandapani, \& Karna, 2017). Kinerja perusahaan tersebut dapat dipengaruhi oleh beberapa indikator, di antaranya adalah internasionalisasi yang diproksikan dengan foreign direct investment atau foreign sales to total sales (Capolupo, Amendolagine, \& Serlenga, 2017; Carney, Duran, van Essen, \& Shapiro, 2017; Miller et al., 2016; Singla \& George, 2013; Vithessonthi, 2016), afiliasi bisnis perusahaan (Bamiatzi, Cavusgil, Jabbour, \& Sinkovics, 2014; Singla \& George, 2013; Upadhyayula et al., 2017), serta riset dan pengembangan (Hsu, Lien, \& Chen, 2015; Vithessonthi \& Racela, 2016).

Pada penelitian ini, proksi yang digunakan untuk mengukur tingkat internasionalisasi perusahaan adalah foreign sales to total sales (FSTS). Ukuran tersebut merupakan salah satu dari empat dimensi aktivitas foreign direct investment (FDI) yang digunakan oleh Singla dan George (2013) serta Vithessonthi dan Racela (2016) untuk mengukur internasionalitas perusahaan. Dalam penelitian terdahulu yang terkait dengan foreign direct investment dan foreign sales to total sales, banyak perdebatan mengenai hubungan antara internasionalisasi dengan kinerja perusahaan, ada yang berdasarkan pada model linear, kuadratik, ataupun sigmoid. Glaum dan Oesterle (2007) mengungkapkan bahwa terdapat beberapa argumen yang mengekspektasikan bahwa ketika perusahaan memiliki keunggulan kompetitif tertentu yang dapat menutupi biaya keasingannya (biaya yang dikeluarkan untuk melakukan aktivitas bisnis di luar negeri), ekspansi perusahaan pada pasar internasional akan meningkatkan kinerja atau profit dari perusahaan tersebut. Kemudian, internasionalisasi hanya akan relevan jika dapat membuat perusahaan tumbuh lebih besar dan mendapatkan pengalaman lebih ketika pasar domestiknya telah sampai pada titik jenuh. Jika perusahaan terletak pada pasar domestik yang sangat besar, perusahaan mungkin tidak perlu melakukan internasionalisasi, sementara jika pasar pada negara asalnya kecil, perusahaan akan terdorong untuk melakukan internasionalisasi guna mendapatkan keuntungan dari skala keekonomiannya (Glaum \& Oesterle, 2007). Strategi internasionalisasi di Indonesia ini banyak dipakai dengan menggunakan foreign sales to total sales. Akan tetapi jarang yang memakai variabel lain, seperti afiliasi dan keberadaan MNC pada proksi tersebut.

Selanjutnya, hal lain yang juga ingin diuji dari penelitian ini adalah pengaruh dari afiliasi bisnis perusahaan terhadap kinerja perusahaan. Afiliasi atau kelompok bisnis merupakan jaringan antar organisasi dari perusahaan semi otonom yang tergabung melalui ikatan kepemilikan, jual beli, kekerabatan antar direktur, dan-atau sosial yang kompleks (Bamiatzi et al., 2014). Koordinasi pada grup bisnis bergantung pada jaringan mekanisme yang cukup kompleks, seperti ikatan ekuitas, hutang, dan komersial, dan terdapat hubungan timbal balik, serta adanya hubungan kekerabatan antar top managers. Menurut Vissa, Greve, \& Chen (2010), organisasi lain merupakan bagian yang penting dari lingkungan bagi organisasi-organisasi yang terafiliasi melalui ikatan kepemilikan (misalnya sebagai divisi), ikatan jaringan (misalnya sebagai anggota grup bisnis), atau ikatan silsilah/genealogical (misalnya sebagai spin-off). Mobilitas personel antar organisasi dan komunikasi antar manajer dari organisasi-organisasi tersebut dapat menghasilkan transfer pengetahuan. Suatu organisasi dapat mengambil pengalaman dari organisasi terafiliasi ketika memilih respons untuk suatu permasalahan (Vissa, Greve, \& Chen, 2010). Namun, penelitian ini tidak hanya terfokus pada pengaruh jumlah afiliasi bisnis terhadap kinerja, tetapi juga pengaruh dari keberadaan afiliasi bisnis perusahaan di luar negeri terhadap kinerja perusahaan tersebut.

Kemudian, diteliti pula pengaruh dari riset dan pengembangan yang dilakukan perusahaan terhadap kinerja dari perusahaan tersebut. Penelitian terdahulu menjelaskan bahwa aktivitas riset 
dan pengembangan dapat menghasilkan keunggulan kompetitif serta menaikkan nilai perusahaan. Dengan melakukan riset dan pengembangan, perusahaan berinovasi sehingga dapat mengembangkan produknya, memenuhi kebutuhan konsumen, meningkatkan daya saing, dan juga meningkatkan profitabilitasnya (Hsu et al., 2015; Vithessonthi \& Racela, 2016). Selain variabelvariabel yang telah dijabarkan di atas, pada penelitian ini juga terdapat faktor-faktor lain yang digunakan sebagai variabel kontrol, seperti usia, ukuran, dan leverage perusahaan.

Penelitian ini memberikan kontribusi tambahan dibandingkan penelitian terdahulu dengan mengombinasikan beberapa variabel internasionalisasi seperti foreign sales to total sales, afiliasi perusahaan yang dilihat dari total afiliasi perusahaan, dan asosiasi MNC untuk variabel data pengambilan afiliasi di luar negeri. Kemudian, studi ini juga mengambil perusahaan manufaktur sebagai sampel karena sektor ini mendominasi kegiatan ekspor di Indonesia. Sesuai dengan pencatatan Badan Pusat Statistik BPS (2016), ekspor dari perusahaan-perusahaan manufaktur masih mendominasi keseluruhan nilai ekspor Indonesia hingga tahun 2016 dan sektor manufaktur merupakan penyumbang terbesar untuk peningkatan ekspor yang terjadi. Oleh karena itu, penelitian ini fokus terhadap industri manufaktur di Indonesia dengan mengukur dampak internasionalisasi terhadap kinerja perusahaan. Secara lebih spesifik, tujuan dilakukannya penelitian ini adalah untuk mengetahui pengaruh internasionalisasi, jumlah afiliasi dan keberadaan afiliasi, dan intensitas riset dan pengembangan terhadap kinerja perusahaan-perusahaan manufaktur di Indonesia.

\section{Telaah Literatur}

\section{Pengaruh Internasionalisasi terhadap Kinerja Perusahaan}

Istilah internasionalisasi biasanya mengacu pada sikap perusahaan terhadap aktivitas bisnis di luar negeri ataupun yang benar-benar melakukan aktivitas bisnis tersebut di luar negeri (Kraus, Mensching, Calabrò, Cheng, \& Filser, 2016; Symeou, Zyglidopoulos, \& Williamson, 2018). Menurut Elango dan Pattnaik (2007), internasionalisasi mengacu pada derajat pendapatan penjualan perusahaan atau operasinya yang dilakukan di luar negara asal. Dalam jurnalnya, Singla \& George (2013) mengeksplorasi dua cara internasionalisasi yang dapat dilakukan oleh perusahaan, yaitu dengan ekspor atau dengan penanaman modal asing (foreign direct investment, FDI).

Pengaruh internasionalisasi memiliki dua arah utama; positif dan negatif. Menurut Singla dan George (2013) terdapat beberapa manfaat yang didapatkan oleh perusahaan ketika melakukan internasionalisasi, diantaranya adalah pengetahuan yang didapatkan dari luar negeri, akses atau arbitrase faktor produksi (input) lebih murah, eksploitasi atas aset spesifik perusahaan dibawa ke setiap pasar asing, akumulasi kekuatan pasar karena keberadaan secara luas di berbagai negara, diversifikasi geografis, dan pengalaman internasionalisasi. Selain manfaat, penelitian terdahulu juga menemukan beberapa kelemahan dari internasionalisasi yang membuat dampak negatif pada kinerja perusahaan. Kelemahan-kelemahan tersebut diantaranya adalah biaya diversifikasi geografis yang diakibatkan oleh adanya liabilitas atas kebaruan dan keasingan (Chen, Hsu, \& Chang, 2016), adanya kompetisi dengan perusahaan-perusahaan pada pasar yang ingin dituju atau dimasuki (García-García, García-Canal, \& Guillén, 2017), adanya komunikasi dan koordinasi yang tidak efektif (Chen et al., 2016), serta risiko finansial seperti fluktuasi nilai tukar mata uang (Altaf \& Shah, 2015)

Internasionalisasi dilakukan oleh perusahaan jika hal tersebut memberikan manfaat yang lebih besar dibandingkan dengan biaya yang dikeluarkan. Dengan begitu, pengaruh dari internasionalisasi terhadap kinerja perusahaan akan menunjukkan hubungan linear positif yang dapat menunjukkan bahwa peningkatan internasionalisasi suatu perusahaan juga akan meningkatkan kinerja perusahaan tersebut. Beberapa penelitian terdahulu menyatakan adanya pengaruh linear positif dari internasionalisasi terhadap kinerja perusahaan (Bamiatzi et al., 2014; García-García et al., 2017). Alasan adanya pengaruh positif dari diversifikasi geografis atau internasionalisasi terhadap performa perusahaan adalah gerakan tersebut memungkinkan perusahaan untuk mendapatkan manfaat dari adanya skala keekonomian (Singla \& George, 2013). Manfaat dari skala keekonomian tersebut 
merupakan hal yang penting bagi perusahaan-perusahaan di negara berkembang, yang pasarnya kemungkinan terlalu kecil untuk memberikan manfaat skala keekonomian yang signifikan. Lebih jauh lagi, diversifikasi geografis jelas memiliki daya tarik dalam ekonomi yang berisiko tinggi yang memiliki ketidakpastian ketidakstabilan dan perubahan struktural yang cepat.

Selain arah positif, hubungan antara internasionalisasi dan kinerja perusahaan juga dijelaskan dalam pengaruh negatifnya. Hal ini dikarenakan internasionalisasi, terutama dengan menggunakan aktivitas FDI, merupakan opsi yang berisiko dan mahal. Ada biaya-biaya yang timbul berkaitan dengan pembangunan sistem manajemen dan jaringan bisnis eksternal ketika melakukan internasionalisasi sehingga perusahaan akan menghadapi tambahan biaya tetap dan overhead, setidaknya pada tahap-tahap awalnya (Singla \& George, 2013). Berdasarkan three-stage model, pada tahap awal, perusahaan akan menghadapi biaya tambahan untuk mempelajari mengenai budaya dan pasar asing (Lin, Liu, \& Cheng, 2011; Symeou et al., 2018; Yaprak et al., 2017). Pada masa tersebut, perusahaan tidak dapat menginternalisasi biaya untuk melakukan operasi internasional sehingga biaya yang dikeluarkan akan lebih tinggi dibandingkan dengan manfaat yang bisa didapatkan (Singla \& George, 2013). Selain itu, berdasarkan penelitian yang dilakukan oleh Donald J. Lecraw terhadap perusahaan di Indonesia yang melakukan internasionalisasi dan berinvestasi di luar negeri, perusahaan cenderung memiliki skala, biaya, dan teknologi yang tidak efisien. Oleh karena itu, kinerja perusahaan Indonesia diduga akan turun seiring dengan peningkatan aktivitas internasionalisasi yang dilakukan dan dengan kata lain memiliki hubungan negatif antara kinerja dan internasionalisasi. Berdasarkan pembahasan tersebut, hipotesis untuk pengaruh variabel ini terhadap kinerja adalah sebagai berikut:

H1: Internasionalisasi berpengaruh positif dan/atau negatif terhadap kinerja perusahaan

\section{Pengaruh Afiliasi Bisnis terhadap Kinerja Perusahaan}

Terdapat dua teori yang menjelaskan kecenderungan perusahaan untuk bergabung ke dalam grup bisnis. Yang pertama yaitu teori ketidaksempurnaan pasar dan yang kedua adalah efektivitas organisasi (Bamiatzi et al., 2014). Ketidaksempurnaan pasar terjadi ketika faktor produksi tersebar secara sempurna antar seluruh pelaku di dalam pasar dan biasanya terjadi di negara berkembang. Pada pasar yang tidak sempurna ini biasanya terdapat masalah seperti keterbatasan akses atas beberapa atau semua faktor produksi, pendanaan eksternal atau terbatasnya perantara keuangan, dan sebagainya. Pada lingkungan yang seperti itu, formasi grup bisnis dianggap dapat menawarkan stabilitas yang dibutuhkan pasar, bertindak sebagai mekanisme antar perusahaan untuk berurusan dengan inefisiensi pasar. Teori efektivitas organisasi menjelaskan bahwa grup bisnis secara umum dianggap dapat meningkatkan kinerja organisasi dengan menyediakan akses yang mudah ke modal dan faktor produksi lainnya, dan secara efektif mendistribusikannya antar seluruh anggota kelompok bisnis .

Selain itu, pada penelitiannya, Singla dan George (2013) menemukan bahwa afiliasi berpengaruh secara positif terhadap kinerja perusahaan dan dapat memoderasi pengaruh dari internasionalisasi terhadap kinerja perusahaan. Walaupun mungkin pada awalnya internasionalisasi yang dilakukan perusahaan mengalami penurunan profitabilitas yang disebabkan oleh biaya untuk melakukan internasionalisasi yang cukup besar, perusahaan akan mendapatkan dukungan dan bantuan yang diperlukan dari perusahaan-perusahaan lain dalam grup tersebut. Jika kinerja perusahaan buruk, perusahaan bisa mendapatkan akses kepada sumber daya yang berharga dari perusahaan lain seperti reputasi, talenta manajerial, dan modal yang dapat membantu perusahaan untuk pulih kembali dalam waktu yang cepat. Perusahaan yang terafiliasi dalam suatu grup bisa mendapatkan kesempatan untuk belajar dari perusahaan-perusahaan lain yang tergabung di dalam jaringan grup tersebut. Dengan begitu, perusahaan-perusahaan ini mencoba untuk mengatasi latemover disadvantage mereka dalam pasar asing. Sebagai contoh, perusahaan yang ada dalam grup dapat belajar dari pengalaman internasionalisasi perusahaan afiliasi lainnya. Afiliasi-afiliasi ini dapat menyediakan koneksi yang penting dan berguna bagi perusahaan anggota yang dapat memberikan 
fasilitas operasi internasionalisasi. Hal ini dapat membuat biaya masuknya ke pasar asing perusahaan yang terafiliasi dalam grup cenderung lebih rendah. Lebih jauh lagi, perusahaan yang terafiliasi memiliki akses yang lebih baik dan lebih cepat terhadap informasi, pengetahuan, sumber daya, pasar, dan teknologi (Singla \& George, 2013).

Pengaruh positif dari afiliasi bisnis terhadap kinerja juga dijelaskan oleh beberapa faktor lain di antaranya dukungan dan bantuan. Dengan adanya afiliasi bisnis, perusahaan akan mendapatkan dukungan dan bantuan yang diperlukan ketika membutuhkan. Sisi baik dari afiliasi grup bisnis menekankan kemampuan dari grup tersebut untuk menangani permasalahan yang terjadi di pasar. Berdasarkan pandangan ini, pada pasar yang sumber dayanya, seperti tenaga kerja yang berkualitas dan dana, terbatas, perusahaan bisa mendapatkan manfaat dari perusahaan lain dalam grup (Bamiatzi et al., 2014; Singh, Nejadmalayeri, \& Mathur, 2007). Dengan begitu, jika kinerja perusahaan sedang buruk, perusahaan bisa mendapatkan akses atas sumber daya yang dibutuhkan sehingga kinerjanya akan pulih kembali dan meningkat dalam waktu cepat. Oleh karena itu, hipotesis yang diuji pada penelitian ini adalah afiliasi bisnis perusahaan dan keberadaan afiliasi perusahaan di luar negeri memberikan dampak positif terhadap kinerja perusahaan tersebut.

H2: Jumlah afiliasi bisnis perusahaan berpengaruh positif terhadap kinerja perusahaan

H3: Keberadaan afiliasi bisnis perusahaan di luar negeri berpengaruh positif terhadap kinerja perusahaan

\section{Pengaruh Intensitas Research \& Development terhadap Kinerja Perusahaan}

Intensitas riset dan pengembangan dapat diartikan sebagai alat bagi perusahaan untuk terlibat dalam akuisisi pengetahuan baik dalam bentuk eksploratif maupun eksploitatif (Vithessonthi, 2016). Penelitian-penelitian terdahulu secara umum banyak yang menyatakan bahwa intensitas R\&D berpengaruh positif terhadap kinerja perusahaan.

Investasi pada R\&D dilakukan dengan tujuan untuk membuat keunggulan kompetitif, meningkatkan nilai perusahaan, dan merefleksikan pilihan stratejik dan komitmen perusahaan untuk mengembangkan kemampuan dan langkah internal perusahaan untuk meningkatkan riset dan penemuan ilmiah. Kemampuan dan langkah-langkah riset dan pengembangan membantu perusahaan mengembangkan pengetahuan teknis baru yang dapat diintegrasikan dengan teknologi, proses organisasional, dan produk dan jasa yang dimiliki perusahaan saat ini (Vithessonthi, 2016). Dengan melakukan R\&D melalui inovasi teknologi, perusahaan dapat mengembangkan atau mengenalkan produk baru atau menurunkan biaya, untuk memenuhi kebutuhan konsumen dengan lebih baik, untuk meningkatkan daya saing, dan juga menjadi yang pertama masuk ke dalam suatu area bisnis atau pasar, dan menghasilkan pertumbuhan profit yang baru, yang dapat meningkatkan profitabilitas perusahaan (Chen \& Hsu, 2010; Vithessonthi \& Racela, 2016). Investasi R\&D merepresentasikan cara perusahan untuk mencari inovasi yang dapat menguatkan posisi pasar produk dan/atau menyediakan kesempatan untuk memasuki wilayah pasar produk yang baru, dengan demikian akan meningkatkan kinerja perusahaan. Oleh karena itu, hipotesis yang dikembangkan dalam penelitian ini adalah sebagai berikut:

H4: Intensitas riset dan pengembangan berpengaruh positif terhadap kinerja perusahaan

\section{Metode Penelitian}

\section{Data dan Sampel Penelitian}

Penelitian ini menggunakan jenis data panel. Metode sampling yang digunakan adalah purposive sampling dengan kriteria; 1). Perusahaan terdaftar di Bursa Efek Indonesia (BEI) pada periode 2011 sampai dengan 2015; 2). Perusahaan manufaktur yang memiliki kelengkapan data, dan telah melakukan internasionalisasi (penjualan di luar negeri atau ekspor). 
Perusahaan manufaktur yang tercatat di Bursa Efek Indonesia pada tahun 2011 hingga tahun 2015 sebanyak 144 perusahaan. Dari total jumlah perusahaan tersebut, yang memenuhi syarat untuk menjadi sampel penelitian adalah sebanyak 62 perusahaan.

\section{Variabel dan Operasionalisasinya}

Penelitian ini menggunakan sembilan variabel, terdiri dari dua variabel dependen yaitu Return on Assets dan Tobin's Q, empat variabel independen yaitu Foreign Sales to Total Sales, Affiliation, MNC Dummy, dan Research and Development Intensity, serta tiga variabel kontrol yaitu Age, Size, dan Leverage.

\section{Return on Assets (ROA)}

Return on Assets merupakan rasio dari laba perusahaan terhadap total aset perusahaan. Rasio ini dapat menunjukkan kemampuan perusahaan dalam menghasilkan laba dengan aset yang dimilikinya. Pada penelitian ini, ROA adalah sebuah indikator yang menggambarkan kinerja perusahaan. Rasio ROA dapat diperoleh dari laporan tahunan perusahaan. Persamaan untuk menghitung ROA:

$$
\text { ROA }=\frac{\text { LabaBersih }}{\text { TotalAsset }}
$$

\section{Tobin's $Q(\mathrm{Q})$}

Tobin's $Q$ ratio dapat digunakan untuk menggambarkan ukuran kinerja finansial/keuangan perusahaan berdasarkan pasar (market-based) (Singla \& George, 2013) atau dapat juga dikatakan nilai perusahaan (firm value). Rasio ini memiliki peran penting dalam berbagai interaksi finansial. Q rasio dapat digunakan untuk berbagai fenomena, seperti perbedaan cross-sectional pada keputusan investasi dan diversifikasi, hubungan antara kepemilikan ekuitas manajerial dan nilai perusahaan, hubungan antara performa manajerial dan keuntungan dari penawaran tender, kesempatan investasi dan respon penawaran tender, pendanaan, dividen, dan kebijakan kompensasi. Tobin's $Q$ Ratio dapat dihitung dengan persamaan:

$Q=\frac{\text { MarketCapitalization+TotalDebt }}{\text { TotalAsset }}$

\section{Foreign Sales to Total Sales (FSTS)}

Foreign Sales to Total Sales pada penelitian ini digunakan untuk menghitung tingkat internasionalisasi perusahaan (Singla \& George, 2013). Aktivitas FDI ini menggunakan 4 (empat) dimensi, diantaranya adalah foreign sales to total sales (FSTS), foreign assets to total assets (FATA), overseas subsidiaries to total number of subsidiaries (OSTS), dan satu dimensi tambahan lagi selain yang dikemukakan oleh Sullivan, yaitu Scope yang menggambarkan persebaran geografis, diekspresikan dengan proporsi jumlah terbanyak negara dengan anak perusahaan. Namun, penelitian ini hanya mengambil salah satu dimensi dari aktivitas FDI, yaitu foreign sales to total sales (FSTS) FSTS adalah ukuran internasionalitas yang paling umum digunakan dalam literatur bisnis internasional. Berikut adalah persamaan FSTS:

$$
\text { FSTS } \frac{\text { Foreign Sales }}{\text { Total Sales }}
$$

\section{Group Affiliation (AFF)}

Variabel Group Affiliation atau sering juga disebut business group adalah jumlah perusahaan yang terafiliasi dengan suatu perusahaan. Banyak definisi mengenai group affiliation/business group. Salah satu definisi dari group affiliation yang lebih sempit berdasarkan sudut pandang ekonomi 
adalah kumpulan dari perusahaan yang independen secara formal beroperasi di pasar yang berbeda di bawah kontrol finansial dan administratif yang sama(Bamiatzi et al., 2014).

\section{AFF = Jumlah Perusahaan Terafiliasi}

\section{MNC Dummy (MNCdum)}

Variabel MNC dummy menunjukkan keberadaan afiliasi bisnis yang dimiliki perusahaan yang terletak di negara lain (Singh et al., 2007; Singla \& George, 2013; Singla, George, \& Veliyath, 2017) Variabel dummy ini menggunakan angka 0 dan 1 untuk mendefinisikan ada atau tidaknya afiliasi perusahaan tersebut. Angka 1 menunjukkan bahwa perusahaan memiliki afiliasi di luar negeri. Sedangkan angka 0 mengartikan bahwa perusahaan tidak memiliki afiliasi di luar negeri.

$0=$ Perusahaan tidak memiliki afiliasi di luar negeri

$1=$ Perusahaan memiliki afiliasi di luar negeri

\section{Research \& Development Intensity (RD)}

Variabel RD merupakan variabel yang menggambarkan intensitas dari riset dan pengembangan yang dilakukan oleh perusahaan. Intensitas riset dan development perusahaan dapat diukur dengan berbagai cara membandingkan biaya yang dikeluarkan perusahaan untuk melakukan aktivitas tersebut terhadap total pendapatan penjualan perusahaan (Hsu et al., 2015; Vithessonthi \& Racela, 2016) Berikut adalah persamaan Research \& Development Intensity

$$
\boldsymbol{R} \boldsymbol{D}=\frac{\text { R\&D Expenditure }}{\text { Total Sales }}
$$

\section{Usia Perusahaan (AGE)}

Variabel ini menggambarkan usia perusahaan dari mulai perusahaan tersebut didirikan hingga periode yang diuji dalam penelitian ini. Untuk pengujiannya, usia perusahaan tidak digunakan secara langsung, namun menggunakan log natural terlebih dahulu.

$A G E=\ln$ Age.

\section{Ukuran Perusahaan (SIZE)}

Berdasarkan penelitian yang sudah ada sebelumnya, terdapat 3 (tiga) proksi yang umum digunakan untuk mengukur ukuran suatu perusahaan, diantaranya adalah total aset, market capitalization, penjualan, dan jumlah pegawai (H. L. Chen et al., 2016; García-García et al., 2017; Kraus et al., 2016; Symeou et al., 2018) Merujuk pada penelitian (Singla \& George, 2013), penelitian ini menggunakan logaritma natural dari penjualansebagai proksi untuk mengukur ukuran perusahaan.

SIZE $=$ In Total Sales

\section{Leverage (LEV)}

Penelitian ini menggunakan leverage sebagai variabel kontrol untuk melihat pengaruh dari perbedaan struktur modal terhadap kinerja perusahaan. Leverage dapat menggambarkan keputusan pendanaan perusahaan. Trade-off theory memprediksi bahwa beberapa perusahaan akan menggunakan pendanaan eksternal untuk menikmati keuntungan seperti manfaat pajak (tax benefit) dari pendanaan dengan menggunakan hutang. Sementara, pecking order theory, yang dijelaskan oleh Qian dan Huang (2016), memprediksi bahwa leverage mengacu pada penggunaan hutang setelah menghabiskan dana internal mereka. Dalam pandangan tersebut, leverage terkait dengan keadaan kesulitan keuangan (financial distress. Leverage merupakan rasio dari total hutang terhadap total aset (Leroy \& Lucotte, 2015). Berikut ini adalah persamaan dari leverage: 
$L E V=\frac{\text { Total Debt }}{\text { Total Assets }}$

\section{Model dan Teknik Analisis Data}

Penelitian ini menggunakan metode regresi data panel sebagai metode pengujian data dengan menggunakan program Stata 13. Metode regresi data panel merupakan metode yang tepat untuk digunakan dalam penelitian ini karena data yang digunakan memiliki gabungan komponen time series dan cross section. Penelitian ini menggunakan Random Effect Model dengan kombinasi 5 time series dan 62 cross sections. Berikut adalah model penelitian yang digunakan dalam penelitian:

Model 1:

$$
\begin{aligned}
& R O A=\beta_{0}+\beta_{1} \text { FSTS }_{i, n}+\beta_{2} A F F_{i, n}+\beta_{3} M_{N C d u m_{i, n}}+\beta_{4} R D_{i, n}+\beta_{5} A G E_{i, n}+\beta_{6} \operatorname{SIZE}_{i, n} \\
& +\beta_{7} L E V_{i, \pi}+\mu
\end{aligned}
$$

Model 2:

$$
\begin{gathered}
Q=\beta_{0}+\beta_{1} F_{S T S}+\beta_{i, n} A F F_{i, n}+\beta_{3} M N C d u m_{i, n}+\beta_{4} R D_{i, n}+\beta_{5} A G E_{i, n}+\beta_{6} S I Z E_{i, n} \\
+\beta_{7} L E V_{i, n}+\mu
\end{gathered}
$$

\section{Hasil dan Pembahasan}

\section{Analisis Statistik Deskriptif}

Tabel 1 di bawah adalah tabel statistik deskriptif dari keseluruhan variabel yang ada dalam penelitian. Total observasi dari penelitian ini berjumlah 310, yang terdiri dari data cross-section 62 perusahaan manufaktur yang tercatat dalam Bursa Efek Indonesia dan data time series dalam periode 5 tahun, yaitu dari tahun 2011 hingga tahun 2015. Selain jumlah observasi, analisis statistik deskriptif memuat beberapa data penting dari variabel-variabel pada penelitian, yaitu mean, standar deviasi, nilai minimum, dan nilai maksimum. Rincian statistik deskriptif tersaji sebagaimana Tabel 1.

Tabel 1. Statistik Deskriptif Variabel Penelitian

\begin{tabular}{cccccc}
\hline Variabel & Obs & Mean & Std. Dev. & Min & Max \\
\hline ROA & 310 & 0.0713 & 0.1009 & -0.1369 & 0.6700 \\
Q & 310 & 1.9368 & 2.5198 & 0.3740 & 18.6404 \\
FSTS & 310 & 0.2307 & 0.2586 & 0.0000 & 0.9992 \\
AFF & 310 & 3.7258 & 7.8332 & 0.0000 & 56.0000 \\
MNCdum & 310 & 0.2194 & 0.4145 & 0.0000 & 1.0000 \\
RD & 310 & 0.0016 & 0.0112 & 0.0000 & 4.5747 \\
\hline
\end{tabular}

\section{Hasil Pengujian Asumsi Klasik}

Terdapat tiga macam pengujian yang digunakan untuk melakukan pengujian asumsi klasik dalam penelitian ini yaitu uji Multikolinearitas, Heteroskedastis, Autokorelasi. Setelah seluruh uji asumsi klasik dilakukan, dapat diketahui bahwa seluruh model yang ada pada penelitian ini tidak memiliki permasalahan multikolinearitas namun memiliki permasalahan heteroskedastisitas yang disebabkan oleh varians dari error yang tidak konstan. Selain itu, model 6, 7, 8, 9, dan 10 memiliki permasalahan autokorelasi.

Untuk mengatasi seluruh masalah pada uji asumsi klasik yang ada pada model regresi tersebut, dalam bukunya yang berjudul Basic Economics, Gujarati (2004) menyatakan bahwa metode Generalized Least Square (GLS) dapat digunakan. Metode ini dapat membuat estimasi menjadi sebuah estimasi yang memenuhi asumsi BLUE. 


\section{Hasil Pengujian Hipotesis}

Pada Tabel 2. dan 3. di bawah, dipaparkan hasil estimasi regresi dari pengaruh internasionalisasi terhadap kinerja perusahaan setelah seluruh permasalahan pada model, seperti multikolinearitas, heteroskedastisitas, dan autokorelasi ditangani dengan menggunakan Generalized Least Square (GLS).

Tabel 2. Hasil Regresi Model Penelitian dengan Variabel Dependen ROA

\begin{tabular}{|c|c|c|c|c|c|}
\hline ROA & 1 & 2 & 3 & 4 & 5 \\
\hline FSTS & $\begin{array}{c}-0.3422 * \\
(0.083)\end{array}$ & & & & $\begin{array}{c}-0.0370 * \\
(0.051)\end{array}$ \\
\hline AFF & & $\begin{array}{c}0.0016 * * \\
(0.015)\end{array}$ & & & $\begin{array}{c}-0.0008 \\
(0.336)\end{array}$ \\
\hline MNCdum & & & $\begin{array}{c}0.0589 * * * \\
(0.000)\end{array}$ & & $\begin{array}{c}0.0711 * * * \\
(0.000)\end{array}$ \\
\hline RD & & & & $\begin{array}{l}0.4929 \\
(0.269)\end{array}$ & $\begin{array}{l}0.6161 \\
(0.150)\end{array}$ \\
\hline AGE & $\begin{array}{c}0.1289 * * * \\
(0.000)\end{array}$ & $\begin{array}{c}0.1309 * * * \\
(0.000)\end{array}$ & $\begin{array}{c}0.1184 * * * \\
(0.000)\end{array}$ & $\begin{array}{c}0.1345^{* * *} \\
(0.000)\end{array}$ & $\begin{array}{c}0.1084 * * * \\
(0.000)\end{array}$ \\
\hline SIZE & $\begin{array}{c}0.0081 * * \\
(0.017)\end{array}$ & $\begin{array}{l}0.0063 \\
(0.106)\end{array}$ & $\begin{array}{c}0.0072 * * \\
(0.027)\end{array}$ & $\begin{array}{c}0.0080 * * \\
(0.019)\end{array}$ & $\begin{array}{c}0.0089 * * * \\
(0.007)\end{array}$ \\
\hline LEV & $\begin{array}{c}-0.1556^{*} \\
(0.079)\end{array}$ & $\begin{array}{l}-0.0143 \\
(0.106)\end{array}$ & $\begin{array}{r}-0.0135 \\
(0.115)\end{array}$ & $\begin{array}{c}-0.0156 * \\
(0.079)\end{array}$ & $\begin{array}{r}-0.0123 \\
(0.150)\end{array}$ \\
\hline Const. & $\begin{array}{c}-0.5538 * * * \\
(0.000)\end{array}$ & $\begin{array}{c}-0.5382 * * * \\
(0.000)\end{array}$ & $\begin{array}{c}-0.5194 * * * \\
(0.000)\end{array}$ & $\begin{array}{c}-0.5804 * * * \\
(0.000)\end{array}$ & $\begin{array}{c}-0.5115^{* * *} \\
(0.000)\end{array}$ \\
\hline $\begin{array}{l}\text { Prob }>\text { chi }^{2} \\
N\end{array}$ & $\begin{array}{c}(0.000) \\
310\end{array}$ & $\begin{array}{c}(0.000) \\
310\end{array}$ & $\begin{array}{c}(0.000) \\
310\end{array}$ & $\begin{array}{c}(0.000) \\
310\end{array}$ & $\begin{array}{c}(0.000) \\
310\end{array}$ \\
\hline
\end{tabular}

Keterangan:

* Signifikansi pada level $10 \%$

** Signifikansi pada level $5 \%$

$* * *$ Signifikansi pada level $1 \%$

Tabel 3. Hasil Regresi Model Penelitian dengan Variabel Dependen Tobin's Q

\begin{tabular}{|c|c|c|c|c|c|}
\hline $\mathrm{Q}$ & 6 & 7 & 8 & 9 & 10 \\
\hline FSTS & $\begin{array}{c}-1.2567 * * * \\
(0.009)\end{array}$ & & & & $\begin{array}{c}-1.2907 * * * \\
(0.004)\end{array}$ \\
\hline AFF & & $\begin{array}{l}0.0242 \\
(0.126)\end{array}$ & & & $\begin{array}{c}-0.04064 * * \\
(0.037)\end{array}$ \\
\hline MNCdum & & & $\begin{array}{c}1.3834 * * * \\
(0.000)\end{array}$ & & $\begin{array}{c}1.987902 * * * \\
(0.000)\end{array}$ \\
\hline $\mathrm{RD}$ & & & & $\begin{array}{c}24.5037 * * \\
(0.023)\end{array}$ & $\begin{array}{c}26.5433^{* *} \\
(0.010)\end{array}$ \\
\hline AGE & $\begin{array}{c}3.2465 * * * \\
(0.000)\end{array}$ & $\begin{array}{c}3.4226 * * * \\
(0.000)\end{array}$ & $\begin{array}{c}3.0901 * * * \\
(0.000)\end{array}$ & $\begin{array}{c}3.4362 * * * \\
(0.000)\end{array}$ & $\begin{array}{c}2.7156^{* * *} \\
(0.000)\end{array}$ \\
\hline SIZE & $\begin{array}{c}0.3071 * * * \\
(0.000)\end{array}$ & $\begin{array}{c}0.2685 * * * \\
(0.001)\end{array}$ & $\begin{array}{c}0.2799 * * * \\
(0.000)\end{array}$ & $\begin{array}{c}0.3088^{* * *} \\
(0.000)\end{array}$ & $\begin{array}{c}0.3521 * * * \\
(0.000)\end{array}$ \\
\hline LEV & $\begin{array}{c}0.8893 * * * \\
(0.000)\end{array}$ & $\begin{array}{c}0.8933 * * * \\
(0.000)\end{array}$ & $\begin{array}{c}0.9273 * * * \\
(0.000)\end{array}$ & $\begin{array}{c}0.8971 * * * \\
(0.000)\end{array}$ & $\begin{array}{c}0.9690 * * * \\
(0.000)\end{array}$ \\
\hline Const. & $-16.6104^{* * *}$ & $-16.8077^{* * *}$ & $-16.0738^{* * *}$ & $-17.6698 * * *$ & $-16.0043 * * *$ \\
\hline Prob > chi & $\begin{array}{l}(0.000) \\
(0.000) \\
310\end{array}$ & $\begin{array}{l}(0.000) \\
(0.000) \\
310\end{array}$ & $\begin{array}{l}(0.000) \\
(0.000) \\
310\end{array}$ & $\begin{array}{l}(0.000) \\
(0.000) \\
310\end{array}$ & $\begin{array}{l}(0.000) \\
(0.000) \\
310\end{array}$ \\
\hline
\end{tabular}

Keterangan:

* Signifikansi pada level 10\%

** Signifikansi pada level 5\%

*** Signifikansi pada level $1 \%$

70 (C) 2018 The Authors. Jurnal Siasat Bisnis. Published by The Management Development Centre, Department of Management, Faculty of Economics, Universitas Islam Indonesia 
Dengan model yang signifikan, variabel-variabel internasionalisasi, afiliasi bisnis, dan R\&D banyak yang berpengaruh signifikan pada tingkat signifikansi yang bervariasi yaitu pada level 1, 5, dan 10 persen, baik pada variabel ROA dan Tobins Q. Oleh karena itu variabel-variabel tersebut dapat dijelaskan lebih lanjut.

\section{Pembahasan}

\section{Pengaruh Foreign Sales to Total Sales (FSTS) terhadap Kinerja Perusahaan}

Model 1, 2, 3, 4, dan 5 pada Tabel 2 menunjukkan hubungan antara internasionalisasi dengan Return on Assets atau kinerja perusahaan berdasarkan tingkat pengembalian terhadap aset. Tabel 3 menggambarkan hubungan antara internasionalisasi dengan Tobin's $Q$ atau kinerja perusahaan pada pasar keuangan. Sementara, model 6, 7, 8, 9, dan 10 menggambarkan hubungan antara internasionalisasi dengan Tobin's $Q$ atau kinerja perusahaan berdasarkan tingkat pengembalian terhadap aset.

Berdasarkan Tabel 2 dan 3, hasil regresi untuk variabel foreign sales to total sales memiliki koefisien negatif dan signifikan. Hal tersebut menunjukkan bahwa aktivitas internasionalisasi yang dilakukan oleh perusahaan akan menurunkan kinerja perusahaan, baik dalam hal tingkat pengembalian asetnya ataupun kinerja perusahaan tersebut di pasar keuangan. Seiring dengan peningkatan internasionalisasinya, kinerja perusahaan akan semakin rendah. Hasil tersebut konsisten dengan hipotesis penelitian yang dikemukakan oleh Lecraw (1993). Menurut penelitian tersebut, hal ini dapat terjadi karena perusahaan yang melakukan internasionalisasi cenderung tidak efisien dalam hal skala, biaya, dan teknologi sehingga biaya yang dikeluarkan untuk melakukan aktivitas internasionalisasi tersebut lebih besar dibandingkan dengan manfaat yang bisa didapatkan perusahaan (Lecraw, 1993). Selain itu, dengan perusahaan meningkatkan operasi mereka di luar negeri, risiko finansial seperti fluktuasi nilai tukar mata uang dan inflasi dapat menutupi manfaat atau keuntungan dari diversifikasi portofolio. Beberapa penelitian terbaru juga menyebutkan bahwa implementasi strategi internasionalisasi membutuhkan biaya investasi yang besar dan dapat dipertimbangkan bahwa internasionalisasi ini sebagai sebuah proyek investasi yang besar dan hal ini menyebabkan adanya pengaruh negatif dari dampak internasionalisasi ini terhadap kinerja perusahaan dalam jangka pendek (Altaf \& Shah, 2015; Vithessonthi \& Racela, 2016)

\section{Pengaruh Afiliasi Bisnis Perusahaan terhadap Kinerja Perusahaan}

Variabel AFF (Afiliasi) merupakan variabel yang menggambarkan jumlah perusahaan-perusahaan yang terafiliasi dengan perusahaan yang terdapat dalam sampel peneltian. Berdasarkan Tabel 2, koefisien dari variabel afiliasi pada model 2 dengan variabel dependen ROA memberikan nilai positif signifikan. Hasil ini menunjukkan bahwa jumlah afiliasi perusahaan berpengaruh positif terhadap Return on Assets perusahaan. Hal ini dikarenakan semakin banyak afiliasi yang dimiliki perusahaan, maka semakin tinggi pula tingkat pengembalian asetnya. Hal tersebut konsisten dengan hipotesis penelitian yang dikembangkan, yaitu perusahaan dapat mengakses berbagai sumber daya meskipun perusahaan menghadapi permasalahan dengan adanya afiliasi sehingga kinerja perusahaan akan tetap pulih dan terus meningkat.

Tobin's Q merupakan indikator kinerja perusahaan yang dilihat dari nilai pasar atau market value-nya. Hasil yang didapat dengan variabel dependen Tobin's Q menunjukkan pengaruh negatif. Dengan begitu, dapat diambil kesimpulan bahwa afiliasi bisnis perusahaan memberikan pengaruh negatif bagi kinerja perusahaan di pasar keuangan. Hal ini terdapat beberapa penyebab diantaranya yaitu perusahaan yang terafiliasi dengan perusahaan sejenis yang memiliki hutang yang tinggi akan mampu memberikan dampak yang buruk terhadap kinerjanya (Singh et al., 2007). Pembebanan hutang dan citra buruk dari perusahaan terafiliasi akan menurunkan nilai pasar perusahaan. Oleh karena itu, walaupun perusahaan afiliasi dapat menikmati manfaat dari grup yang ada, perusahaan 
bisa saja memikul liabilitas dari afiliasi grup bisnis tersebut, misalnya dengan buruknya nama suatu perusahaan afiliasi, perusahaan juga dapat terkena dampaknya dengan turunnya nilai perusahaan(Ma, Yao, \& Xi, 2006). Sebagai dampaknya, kepercayaan investor pada perusahaan juga dapat menurun (Vithessonthi, 2016).

Hal kedua yang melatarbelakangi adanya pengaruh negatif ini adalah ada biaya yang tidak efisien. Hal ini dikarenakan biaya yang tidak efisien dari adanya grup yang terafiliasi tersebut dapat menyebabkan menurunnya kinerja perusahaan dari sisi operasional sehingga mengakibatkan hubungan terbalik diantara kedua variabel tersebut (Assaf, Josiassen, Ratchford, \& Barros, 2012; Singh et al., 2007)

Variabel Afiliasi bisnis lain yang digunakan yaitu dengan menggunakan variabel MNC dummy yang menyatakan ada atau tidaknya afiliasi perusahaan yang berlokasi di luar negeri. Tabel 2 dan 3 menunjukkan bahwa hasil regresi dari variabel ini adalah positif signifikan. Hasil tersebut menandakan bahwa keberadaan afiliasi perusahaan di luar negeri memberikan pengaruh positif terhadap kinerja perusahaan, baik dalam hal Return on Assets, maupun dalam hal kinerja perusahaan di pasar keuangan.

Jika perusahaan memiliki afiliasi di luar negeri, kinerja perusahaan cenderung akan meningkat, baik dalam hal tingkat pengembalian terhadap aset ataupun dalam hal menarik investor untuk berinvestasi pada perusahaan. Hal ini dikarenakan perusahaan yang terafiliasi memiliki beberapa manfaat dan kelebihan yang dapat meningkatkan kinerjanya. Hal ini dikarenakan adanya beberapa hal diantaranya yaitu adanya sharing informasi, sumber daya, dan kapabilitas anggota di grup itu sendiri. Pertama, grup bisnis biasanya mempunyai sejarah panjang dengan mempunyai hubungan dengan lingkungan eksternal (Singh, Pattnaik, Gaur, \& Ketencioglu, 2018). Hubungan eksternal tersebut mencakup pembuat kebijakan, pemerintah, non-governmental organizations, pemasok, dan distributor. Hubungan ini mampu meningkatkan kualitas dan pemberian informasi yang cepat terkait kesempatan yang ada saat ini dan masa depan, dan hal ini hanya akan dapat diambil manfaatnya dengan perusahaan yang terafiliasi satu sama lainnya.

\section{Pengaruh Intensitas Research \& Development terhadap Kinerja Perusahaan}

Variabel RD atau variabel research and development intensity merupakan variabel yang mengukur rasio biaya yang dikeluarkan perusahaan untuk melakukan penelitian dan pengembangan terhadap total penjualan/pendapatan yang diperolehnya. Dari tabel 2 dan 3 dapat dilihat bahwa intensitas riset dan pengembangan memberikan pengaruh positif terhadap return on asset perusahaan dan kinerja perusahaan di pasar keuangan (Tobin's Q). Hasil tersebut menunjukkan bahwa semakin perusahaan memperbesar intensitasnya dalam melakukan penelitian dan pengembangan, kinerja perusahaan juga akan semakin meningkat.

Hal ini konsisten dengan hipotesis yang dikembangkan dalam penelitian, yaitu investasi perusahaan pada hal penelitian dan pengembangan memperbesar kemungkinan terjadinya inovasi yang dapat membuat profitabilitas perusahaan meningkat (Warusawitharana, 2008). Teori berdasarkan sumber daya menyatakan bahwa perusahaan yang memiliki sumberdaya dan kemampuan berharga yang tidak dapat diimitasi dan tidak dapat disubstitusi akan memiliki keuntungan dibandingkan dengan perusahaan lainnya dalam hal peningkatan kinerja. Investasi pada sumberdaya berharga seperti riset dan pengembangan memiliki peran penting dalam hal tersebut. Walaupun biaya yang dikeluarkan besar, keuntungan yang dihasilkan pun bisa jauh lebih besar dalam bentuk kemampuan internal untuk melakukan inovasi dan meningkatkan performa (Ghaffar \& Khan, 2014).

\section{Simpulan dan Saran}

Hasil dari penelitian ini menjelaskan 3 temuan. Pertama, pengaruh variabel internasionalisasi berpengaruh signifikan negatif terhadap kinerja perusahaan, baik secara profitabilitas (ROA), maupun kinerja perusahaan pada pasar keuangan (Tobin's Q). Hal ini dikarenakan biaya yang 
dikeluarkan oleh perusahaan untuk melakukan aktivitas internasionalisasi lebih besar dibandingkan dengan manfaat yang diperolehnya. Hal tersebut dapat diakibatkan karena inefisiensi dalam hal biaya maupun tekonologi (Lecraw, 1993), dan perusahaan yang terafiliasi dengan perusahaan sejenis yang memiliki hutang yang tinggi akan mampu memberikan dampak yang buruk terhadap kinerjanya (Singh et al., 2007). Oleh karena itu, pembebanan hutang dan citra buruk dari perusahaan terafiliasi akan menurunkan nilai pasar perusahaan.

Kedua, afiliasi bisnis perusahaan berpengaruh positif terhadap tingkat pengembalian aset perusahaan. Hal ini ditunjukkan oleh variabel AFF pada hasil regresi dari model dengan variabel dependen ROA yang memiliki koefisien positif. Hasil tersebut menunjukkan bahwa semakin banyak perusahaan memiliki afiliasi bisnis, perusahaan akan semakin mudah untuk menghadapi masalahmasalahnya sehingga kinerjanya dapat meningkat. Sedangkan terhadap Tobin's Q, pengaruh dari afiliasi adalah negatif, yang berarti semakin banyak afiliasi bisnis perusahaan, kinerja perusahaan di pasar keuangan akan menurun. Hal ini dapat disebabkan dari adanya cost of group affiliation, misalnya ketika nama perusahaan afiliasi sedang buruk, perusahaan juga akan terkena imbasnya (Ma et al., 2006). Keberadaan afiliasi bisnis perusahaan di luar negeri dapat memberikan pengaruh positif bagi kinerja perusahaan, sesuai dengan yang ditunjukkan oleh variabel MNCdum pada hasil regresi. Hal tersebut dikarenakan keberadaan afiliasi di luar negeri dapat membuat perusahaan mendapatkan akses yang lebih mudah atas sumber daya yang langka dan sulit didapatkan, serta memberikan manfaat-manfaat lain seperti skala dan cakupan yang lebih luas (Singla \& George, 2013).

Ketiga, intensitas riset dan pengembangan, yaitu yang ditunjukkan dengan variabel RD pada hasil regresi, berpengaruh positif terhadap kinerja perusahaan. Semakin tinggi intensitas riset dan pengembangan suatu perusahaan, akan semakin meningkat juga kinerjanya. Hal ini dapat terjadi karena dengan melakukan penelitian dan pengembangan, perusahaan bisa menghasilkan inovasi, baik dalam hal teknologi ataupun produk, yang dapat meningkatkan profitabilitasnya (Warusawitharana, 2008).

Berdasarkan hasil penelitian yang telah dilakukan, keberadaan afiliasi bisnis perusahaan di luar negeri juga baik bagi perusahaan karena dapat membantu perusahaan untuk mendapatkan akses atas sumber daya yang langka di negara asal perusahaan, serta dapat memperluas cakupan perusahaan hingga ke luar negeri. Selain itu, riset dan pengembangan juga sebaiknya terus dilakukan oleh perusahaan karena seiring dengan perkembangan yang terjadi pada lingkungan, perusahaan perlu terus melakukan inovasi agar dapat meningkatkan kualitas produknya, memenuhi kebutuhan konsumen, dan nantinya dapat meningkatkan kinerja perusahaan.

\section{Daftar Referensi}

Altaf, N., \& Shah, F. A. (2015). Internationalization and firm performance of Indian firms: Does product diversity matter? Pacific Science Review B: Humanities and Social Sciences, 1(2), 76-84. https://doi.org/10.1016/j.psrb.2016.05.002

Assaf, A. G., Josiassen, A., Ratchford, B. T., \& Barros, C. P. (2012). Internationalization and Performance of Retail Firms: A Bayesian Dynamic Model. Journal of Retailing, 88(2), 191205. https://doi.org/10.1016/j.jretai.2011.11.005

Bamiatzi, V., Cavusgil, S. T., Jabbour, L., \& Sinkovics, R. R. (2014). Does business group affiliation help firms achieve superior performance during industrial downturns? An empirical examination. International Business Review, 23(1), 195-211. https://doi.org/10.1016/j.ibusrev.2013.04.003

Boso, N., Adeola, O., Danso, A., \& Assadinia, S. (2017). The effect of Export Marketing Capabilities on Export Performance: Moderating Role of Dysfunctional Competition. Industrial Marketing Management, (September). https://doi.org/10.1016/j.indmarman.2017.09.006

Capolupo, R., Amendolagine, V., \& Serlenga, L. (2017). Internationalization modes and productivity 
of Italian manufacturing: Some firm-level evidence. International Economics, 152(July), 79_ 90. https://doi.org/10.1016/j.inteco.2017.06.004

Carney, M., Duran, P., van Essen, M., \& Shapiro, D. (2017). Family firms, internationalization, and national competitiveness: Does family firm prevalence matter? Journal of Family Business Strategy, 8(3), 123-136. https://doi.org/10.1016/j.jfbs.2017.06.001

Chen, H., \& Hsu, C. W. (2010). Internationalization, resource allocation and firm performance. Industrial Marketing Management, 39(7), 1103-1110. https://doi.org/10.1016/j.indmarman.2009.10.001

Chen, H. L., Hsu, W. T., \& Chang, C. Y. (2016). Independent directors' human and social capital, firm internationalization and performance implications: An integrated agency-resource dependence view. International Business Review, 25(4), 859-871. https://doi.org/10.1016/j.ibusrev.2015.10.010

Demirkesen, S., \& Ozorhon, B. (2017). Impact of Integration Management on Construction Project Management Performance. International Journal of Project Management, 35(8), 1639-1654. https://doi.org/10.1016/j.ijproman.2017.09.008

Elango, B., \&Pattnaik, C. (2007). Building capabilities for international operations through networks: A study of Indian firms. Journal of International Business Studies, 38(4), 541-555.

García-García, R., García-Canal, E., \& Guillén, M. F. (2017). Rapid internationalization and longterm performance: The knowledge link. Journal of World Business, 52(1), 97-110. https://doi.org/10.1016/j.jwb.2016.09.005

Ghaffar, A., \& Khan, W. A. (2014). Impact of Research and Development on Firm Performance. International Journal of Accounting and Financial Reporting, 4(1), 357. https://doi.org/10.5296/ijafr.v4i1.6087

Glaum, M., \& Oesterle, M.-J. (2007). 40 years of research on internationalization and firm performance: More questions than answers? Management International Review, 47(3), 307317. https://doi.org/10.1007/s11575-007-0018-0

Hsu, C. W., Lien, Y. C., \& Chen, H. (2015). R\&D internationalization and innovation performance. International Business Review, 24(2), 187-195. https://doi.org/10.1016/j.ibusrev.2014.07.007

Kraus, S., Mensching, H., Calabrò, A., Cheng, C. F., \& Filser, M. (2016). Family firm internationalization: A configurational approach. Journal of Business Research, 69(11), 5473-5478. https://doi.org/10.1016/j.jbusres.2016.04.158

Lecraw, D. J. (1993). Outward Direct Investment by Indonesian Firms: Motivation and Effects Author ( $\mathrm{s}$ ): Donald J . Lecraw Published by: Palgrave Macmillan Journals Stable URL: http://www.jstor.org/stable/154780. Journal of International Business Studies, 24(3), 589600.

Leroy, A., \& Lucotte, Y. (2015). Is there a competition-stability trade-off in European banking? Journal of International Financial Markets, Institutions and Money, 46, 199-215. https://doi.org/10.1016/j.intfin.2016.08.009

Lin, W. T., Liu, Y., \& Cheng, K. Y. (2011). The internationalization and performance of a firm: Moderating effect of a firm's behavior. Journal of International Management, 17(1), 83-95. https://doi.org/10.1016/j.intman.2010.12.004

Ma, X., Yao, X., \& Xi, Y. (2006). Business group affiliation and firm performance in a transition economy: A focus on ownership voids. Asia Pacific Journal of Management, 23(4), 467- 


\section{3. https://doi.org/10.1007/s10490-006-9011-6}

Miller, S. R., Lavie, D., \& Delios, A. (2016). International intensity, diversity, and distance: Unpacking the internationalization-performance relationship. International Business Review, 25(4), 907-920. https://doi.org/10.1016/j.ibusrev.2015.12.003

Purnama, C., \& Subroto, W. T. (2016). Competition Intensity, Uncertainty Environmental on The Use of Information Technology and Its Impact on Business Performance Small and Medium Enterprises. International Review of Management and Marketing, 6(4), 984-992. Retrieved from https://www.scopus.com/inward/record.uri?eid=2-s2.084992549228\&partnerID=40\&md5=576870cf5874ad42287daf75f6eb4039

Qian, M., \& Huang, Y. (2016). Political institutions, entrenchments, and the sustainability of economic development - A lesson from rural finance. China Economic Review, 40, 152178. https://doi.org/10.1016/j.chieco.2016.06.005

Singh, D., Pattnaik, C., Gaur, A. S., \& Ketencioglu, E. (2018). Corporate expansion during promarket reforms in emerging markets: The contingent value of group affiliation and diversification. Journal of Business Research, 82(September 2017), 220-229. https://doi.org/10.1016/j.jbusres.2017.09.043

Singh, M., Nejadmalayeri, A., \& Mathur, I. (2007). Performance impact of business group affiliation: An analysis of the diversification-performance link in a developing economy. Journal of Business Research, 60(4), 339-347. https://doi.org/10.1016/j.jbusres.2006.10.024

Singla, C., \& George, R. (2013). Internationalization and performance: A contextual analysis of Indian firms. Journal of Business Research, 66(12), 2500-2506. https://doi.org/10.1016/j.jbusres.2013.05.041

Singla, C., George, R., \& Veliyath, R. (2017). Ownership structure and internationalization of Indian firms. Journal of Business Research, 81(August), 130-143. https://doi.org/10.1016/j.jbusres.2017.08.016

Symeou, P. C., Zyglidopoulos, S., \& Williamson, P. (2018). Internationalization as a driver of the corporate social performance of extractive industry firms. Journal of World Business, 53(1), 27-38. https://doi.org/10.1016/j.jwb.2017.07.004

Upadhyayula, R. S., Dhandapani, K., \& Karna, A. (2017). The Role of Cluster Presence and Quality Certification in Internationalization and Performance of Offshore Service Providers. Journal of International Management, 23(1), 72-86. https://doi.org/10.1016/j.intman.2016.11.004

Vithessonthi, C. (2016). Capital investment, internationalization, and firm performance: Evidence from Southeast Asian countries. Research in International Business and Finance, 38, 393403. https://doi.org/10.1016/j.ribaf.2016.04.019

Vithessonthi, C., \& Racela, O. C. (2016). Short- and long-run effects of internationalization and R\&D intensity on firm performance. Journal of Multinational Financial Management, 34, 28-45. https://doi.org/10.1016/j.mulfin.2015.12.001

Warusawitharana, M. (2008). Research and Development, Profits and Firm Value: A Structural Estimation. Finance and Economics Series, Board of Governors of the Federal Reserve System, (September), 1-42.

Yaprak, A., Yosun, T., \& Cetindamar, D. (2017). The influence of firm-specific and country-specific advantages in the internationalization of emerging market firms: Evidence from Turkey. International Business Review, 27(August 2017), 198-207. https://doi.org/10.1016/j.ibusrev.2017.07.001 